Article

\title{
The Gersdorffite-Bismuthinite-Native Gold Association and the Skarn-Porphyry Mineralization in the Kamariza Mining District, Lavrion, Greece ${ }^{\dagger}$
}

\author{
Panagiotis Voudouris $\left.{ }^{1, *} \mathbb{(}\right)$, Constantinos Mavrogonatos ${ }^{1}\left(\mathbb{D}\right.$, Branko Rieck $^{2}$, Uwe Kolitsch ${ }^{2,3}$, \\ Paul G. Spry ${ }^{4}\left(\mathbb{D}\right.$, Christophe Scheffer $^{5}$, Alexandre Tarantola ${ }^{6}(\mathbb{0})$, Olivier Vanderhaeghe ${ }^{7}$, \\ Emmanouil Galanos ${ }^{1}$, Vasilios Melfos ${ }^{8}{ }^{(0)}$, Stefanos Zaimis ${ }^{9}$, Konstantinos Soukis ${ }^{1}{ }^{(0)}$ and \\ Adonis Photiades 10 (D) \\ 1 Department of Geology \& Geoenvironment, National and Kapodistrian University of Athens, \\ 15784 Athens, Greece; kmavrogon@geol.uoa.gr (C.M.); manosgalanos@gmail.com (E.G.); \\ soukis@geol.uoa.gr (K.S.) \\ 2 Institut für Mineralogie und Kristallographie, Universität Wien, 1090 Wien, Austria; branko.rieck@live.at \\ 3 Mineralogisch-Petrographische Abteilung, Naturhistorisches Museum, 1010 Wien, Austria; \\ uwe.kolitsch@NHM-WIEN.AC.AT \\ 4 Department of Geological and Atmospheric Sciences, Iowa State University, Ames, IA 50011, USA; \\ pgspry@iastate.edu \\ 5 Département de Géologie et de Génie Géologique, Université Laval, Québec, QC G1V 0A6, Canada; \\ christophe.scheffer.1@ulaval.ca \\ 6 Université de Lorraine, CNRS, GeoRessources UMR 7359, Faculté des Sciences et Technologies, \\ F-54506 Vandoeuvre-lès-Nancy, France; alexandre.tarantola@univ-lorraine.fr \\ 7 Université de Toulouse, Géosciences Environnement Toulouse (GET), UMR 5563 CNRS, \\ F-31400 Toulouse, France; Olivier.VANDERHAEGHE@Get.omp.eu \\ 8 Department of Mineralogy-Petrology-Economic Geology, Faculty of Geology, Aristotle University of \\ Thessaloniki, 54124 Thessaloniki, Greece; melfosv@geo.auth.gr \\ 9 Institut für Mineralogie, TU Bergakademie Freiberg, 09599 Freiberg, Germany; szaimis@gmail.com \\ 10 Institute of Geology and Mineral Exploration (I.G.M.E.), 13677 Acharnae, Greece; fotiadis@igme.gr \\ * Correspondence: voudouris@geol.uoa.gr; Tel.: +30-210-7274129 \\ + The paper is an extended version of our paper published in 1st International Electronic Conference on \\ Mineral Science.
}

Received: 15 October 2018; Accepted: 11 November 2018; Published: 16 November 2018

\begin{abstract}
Vein-type Pb-Ni-Bi-Au-Ag mineralization at the Clemence deposit in the Kamariza and "km3" in the Lavrion area, was synchronous with the intrusion of a Miocene granodiorite body and related felsic and mafic dikes and sills within marbles and schists in the footwall of (and within) the Western Cycladic detachment system. In the Serpieri deposit (Kamariza area), a porphyry-style pyrrhotite-arsenopyrite mineralized microgranitic dike is genetically related to a garnet-wollastonite bearing skarn characterized by a similar base metal and $\mathrm{Ni}$ (up to $219 \mathrm{ppm}$ ) enrichment. The $\mathrm{Ni}-\mathrm{Bi}-\mathrm{Au}$ association in the Clemence deposit consists of initial deposition of pyrite and arsenopyrite followed by an intergrowth of native gold-bismuthinite and oscillatory zoned gersdorffite. The zoning is related to variable $\mathrm{As}, \mathrm{Ni}$, and $\mathrm{Fe}$ contents, indicating fluctuations of arsenic and sulfur fugacity in the hydrothermal fluid. A late evolution towards higher sulfur fugacity in the mineralization is evident by the deposition of chalcopyrite, tennantite, enargite, and galena rimming gersdorffite. At the "km3" locality, Ni sulfides and sulfarsenides, vaesite, millerite, ullmannite, and polydymite, are enclosed in gersdorffite and/or galena. The gersdorffite is homogenous and contains less Fe (up to $2 \mathrm{wt} . \%$ ) than that from the Clemence deposit (up to $9 \mathrm{wt} . \%$ ). Bulk ore analyses of the Clemence ore reveal $\mathrm{Au}$ and $\mathrm{Ag}$ grades both exceeding $100 \mathrm{~g} / \mathrm{t}, \mathrm{Pb}$ and $\mathrm{Zn}>1 \mathrm{wt} . \%$, Ni up to $9700 \mathrm{ppm}$, Co up to $118 \mathrm{ppm}, \mathrm{Sn}>100 \mathrm{ppm}$, and $\mathrm{Bi}>2000 \mathrm{ppm}$. The "km3" mineralization is enriched in Mo (up to $36 \mathrm{ppm}$ ), Ni (>1 wt.\%), and Co (up to $1290 \mathrm{ppm}$ ). Our data further support a magmatic
\end{abstract}


contribution to the ore-forming fluids, although remobilization and leaching of metals from previous mineralization and/or host rocks, through the late involvement of non-magmatic fluid in the ore system, cannot be excluded.

Keywords: nickel sulfides-sulfarsenides; bismuth; gold; oscillatory zoning; Lavrion; Greece

\section{Introduction}

The Lavrion district in Greece is part of the Attic-Cycladic metamorphic core complex, and contains a variety of ore types including porphyry Mo-W, skarn Fe-Cu-Bi-Te, carbonate-replacement $\mathrm{Pb}-\mathrm{Zn}-\mathrm{Cu}-\mathrm{As}-\mathrm{Sb}-\mathrm{Ag} \pm \mathrm{Au}-\mathrm{Bi}$, and vein/breccia Pb-Zn-Cu-As-Sb-Ag-Au-Ni-Bi [1-7]. Mineralization was synchronous with the intrusion of a Miocene granodiorite body in the footwall and hanging wall of the Western Cycladic detachment system (WCDS) and related felsic dikes and sills within marbles and schists, which locally crosscut the detachment. Although dominated by base metal sulfides, nickel- and to a lesser extent cobalt-bearing metallic minerals have been described from several sites in the Lavrion district, for example, at the Kamariza, Plaka and "km3" deposits. Gersdorffite, rammelsbergite, nickeline, and safflorite were described from the " $\mathrm{km} 3$ " site by Marinos and Petraschek [1], Wendel and Markl [8], and Rieck et al. [9]. Gersdorffite related to sulfides and fluorite was found along the detachment fault in the Villia deposit and in chimneys from the Jean Baptiste deposit [7]. Kolitsch et al. [6] described the following Ni and Co minerals at Plaka (145 Adit), associated with pyrrhotite-bearing skarn: cattierite, cobaltite, pentlandite, polydymite, siegenite, ullmannite, and violarite. Polydymite, ullmannite, vaesite, and violarite were detected at " $\mathrm{km} 3$ " within the galena-nickelskutterudite-gersdorffite assemblage. Vaesite and violarite were also reported from the Jean Baptiste deposit (Kamariza) [6]. Gersdorffite associated with gold was described by Voudouris et al. [4] from the Clemence deposit, in the Kamariza area.

This paper evaluates the primary mineralogical and chemical characteristics of the breccia/vein and carbonate-replacement mineralization at the Clemence deposit (Kamariza district) and the " $\mathrm{km} 3$ " district, which both host $\mathrm{Ni}-\mathrm{Au}$-Bi ores, and provides preliminary information on their potential genetic relationship to intrusive rocks in the Lavrion district $[6,10]$. The present study also describes the mineralogy and geochemistry of intrusive bodies in the Kamariza area and describes a new occurrence of skarn and porphyry-style mineralization in the Serpieri deposit, which is spatially associated with a felsic dike intruding marbles [6,9]. A comparison between sulfide assemblages within the Kamariza intrusives and the studied breccia/vein and carbonate-replacement mineralization provides information about the formation conditions of the Lavrion ore deposits. Finally, phase diagrams were used to constrain the physicochemical conditions of ore formation at Kamariza.

\section{Materials and Methods}

Samples were collected underground from the Clemence, Jean Baptiste, and Serpieri mines in the Kamariza area and from the "km3" district. Forty-three thin and polished sections of host-rocks, skarn, and sulfide mineralization were studied by optical microscopy and a JEOL JSM 5600 scanning electron microscope, equipped with backscattered imaging capabilities, at the Department of Mineralogy and Petrology, University of Athens. Quantitative analyses were carried out at the University of Athens, Department of Geology, using a JEOL JSM 5600 scanning electron microscope equipped with automated OXFORD ISIS 300 energy-dispersive analysis system. Analytical conditions were $20 \mathrm{kV}$ accelerating voltage, $0.5 \mathrm{nA}$ beam current, $<2 \mu \mathrm{m}$ beam diameter, and $60 \mathrm{~s}$ count times. The X-ray lines used were $\mathrm{AlK} \alpha, \operatorname{SiK} \alpha, \operatorname{CaK} \alpha, \operatorname{CeL} \alpha, \operatorname{NdL} \alpha, \operatorname{LaL} \alpha, \operatorname{KK} \alpha, \operatorname{FeK} \alpha, \operatorname{NaK} \alpha, \operatorname{TiK} \alpha, \operatorname{MgK} \alpha$, and FK $\alpha$. The standards used were orthoclase, albite and wollastonite for $\mathrm{K}, \mathrm{Na}$, Si and $\mathrm{Ca}$; pyrite for $\mathrm{Fe}$; and synthetic $\mathrm{Ti}, \mathrm{MgO}, \mathrm{Al}_{2} \mathrm{O}_{3}, \mathrm{CeO}_{2}, \mathrm{NdF}_{3}, \mathrm{LaB}_{6}, \mathrm{SrF}_{2}$ for $\mathrm{Ti}, \mathrm{Mg}, \mathrm{Al}, \mathrm{Ce}, \mathrm{Nd}$, La and F. The chemical composition of sulfides, sulfosalts, and native elements were determined with a Cameca-SX 100 
wavelength-dispersive electron microprobe at the Department of Mineralogy and Petrology, University of Hamburg, Germany. Operating conditions were $20 \mathrm{kV}$ and $20 \mathrm{nA}$, with a beam diameter $<1 \mu \mathrm{m}$. The following X-ray lines were used: $\operatorname{AgL} \alpha, \operatorname{AsL} \alpha, \operatorname{AuM} \alpha, \operatorname{BiM} \beta, \operatorname{CuK} \alpha, \operatorname{FeK} \alpha, \operatorname{HgM} \alpha, \operatorname{PbM} \alpha, \operatorname{SK} \alpha$, $\mathrm{SbL} \alpha, \operatorname{SeL} \alpha, \mathrm{TeL} \alpha$, and $\mathrm{ZnK} \alpha$. Pure elements (for Ag, $\mathrm{Au}, \mathrm{Bi}, \mathrm{Se}, \mathrm{Te}$ ), pyrite and chalcopyrite (for $\mathrm{Fe}$, $\mathrm{Cu}$, and $\mathrm{S}$ ), galena (for $\mathrm{Pb}$ ), sphalerite (for $\mathrm{Zn}$ ), $\mathrm{HgS}$ (for $\mathrm{Hg}$ ), $\mathrm{Sb}_{2} \mathrm{~S}_{3}$ (for $\mathrm{Sb}$ ) and synthetic GaAs (for As) were used as standards. Three fresh rock samples from the Kamariza intrusive rocks were selected for whole-rock geochemical analysis. Major elements were analyzed on lithium tetraborate glass beads by X-ray fluorescence (XRF) using a Philips PW 1410 spectrometer at the Institute of Mineralogy and Petrology at Hamburg University (Germany). Detection limits for trace elements are $10 \mathrm{ppm}$ for Ba, $\mathrm{Cr}, \mathrm{Cu}, \mathrm{Nb}, \mathrm{Ni}, \mathrm{Pb}, \mathrm{Rb}, \mathrm{Sr}, \mathrm{V}, \mathrm{Y}, \mathrm{Zn}, \mathrm{Zr}, \mathrm{Th} ; 20 \mathrm{ppm}$ for La, Nd; and $25 \mathrm{ppm}$ for Ce. The precision for major elements is better than $\pm 0.4 \%$ for $\mathrm{SiO}_{2}, \pm 0.13 \%$ for $\mathrm{Al}_{2} \mathrm{O}_{3}$, and $\mathrm{Fe}_{2} \mathrm{O}_{3}, \pm 0.22 \%$ for $\mathrm{MgO}$, $\pm 0.10 \%$ for $\mathrm{CaO}, \pm 0.33 \%$ for $\mathrm{Na}_{2} \mathrm{O}$, and $0.02-0.04 \%$ for $\mathrm{K}_{2} \mathrm{O}, \mathrm{TiO}_{2}, \mathrm{P}_{2} \mathrm{O}_{5}$. and $\mathrm{SO}_{3}$. Phase diagrams were constructed using the methods of Garrels and Christ [11] and Henley et al. [12].

\section{Geology and Mineralization}

The Lavrion district belongs to the Attic-Cycladic Crystalline Belt, which is characterized by a Late Cretaceous-Eocene deformation and blueschist facies metamorphism, followed by Late Oligocene to Miocene post-orogenic extension in the back-arc region of the Aegean continental crust, leading to exhumation of metamorphic core complexes into greenschist facies that overprint the high-pressure rocks [13-22]. A lower (or Kamariza) unit composed of a sequence of Triassic-Early Jurassic age rocks metamorphosed to blueschist facies and retrogressed to greenschist-amphibolite facies, consists of a lower marble, the Kamariza schists (and marbles), and an upper marble formation [1,15,21]. The upper tectonic unit, also referred to as the Lavrion or Cycladic Blueschist Unit, comprises a phyllitic nappe of Late Cretaceous age $[1,15,16]$. It consists of a volcano-sedimentary formation, a mafic meta-ophiolite, and crystalline limestone $[15,17,18]$.

Contacts between the upper and lower units are considered to be part of the Western Cycladic detachment system (Figure 1) [20,21]. A Miocene I-type granodiorite intrusion is exposed at Plaka (Figure 1), and was synchronous with the extensional detachment faulting $[7,23,24]$. Several occurrences of granite and granodiorite porphyry laccoliths, pipes, dikes and sills are exposed throughout the Lavrion district $[1,7,16,24]$. East to west trending diorite and granite dikes and sills crosscut the lower marble and the Kamariza schists in the Kamariza area. According to Marinos and Petrascheck [1], the largest dikes are found north of the "Serpieri 1" shaft, between the "Serpieri 1", "Ilarion 1" shafts, and south of the Ilarion orebody (Figure 1b). The dikes are locally boudinaged, thus testifying to an emplacement before the activation of the WCDS. The mafic dikes are equigranular to porphyritic rocks consisting of plagioclase and biotite with interstitial quartz and albite. They have undergone propylitic alteration (Figure 2a) and are characterized by chlorite, carbonates, actinolite, pyrite, and chalcopyrite that replaced primary minerals and/or which occur in veinlets and as disseminations in the groundmass. Adjacent to the marbles and the orebodies, the mafic dikes are pervasively altered to quartz-sericite \pm kaolinite \pm carbonates, and contain disseminated or vein sulfides. Felsic dikes at the Serpieri mine consist of primary plagioclase, biotite, and muscovite associated with quartz and orthoclase, the latter in micrographic intergrowth (Figures 2a, and 3a,b). Allanite-(Ce) and synchysite- $(\mathrm{Ce})\left(\mathrm{CaCe}\left[\mathrm{CO}_{3}\right]_{2} \mathrm{~F}\right)$ are included in plagioclase and in late magmatic quartz (Figure $3 \mathrm{c}, \mathrm{d}$ ). Biotite was partly replaced by chlorite. Figure 4 shows the geochemical characteristics of mafic and felsic igneous rocks in the Kamariza district. The Serpieri magmatic rocks analyzed in the present study (Table 1), plot in the calc-alkaline to high-K calc-alkaline field (Figure 4a) of Pecerrillo and Taylor [25], and are classified as microgranite in the TAS classification diagram of Middlemost [26] (Figure 4b). Based on the discrimination diagrams of Schand [27] and Maniar and Piccoli [28], they are I-type granitoids and metaluminous to slightly peraluminous with ASI $<1.1$ (Figure $4 \mathrm{c}, \mathrm{d}$ ), and can be considered subvolcanic equivalents of the Plaka granite. 


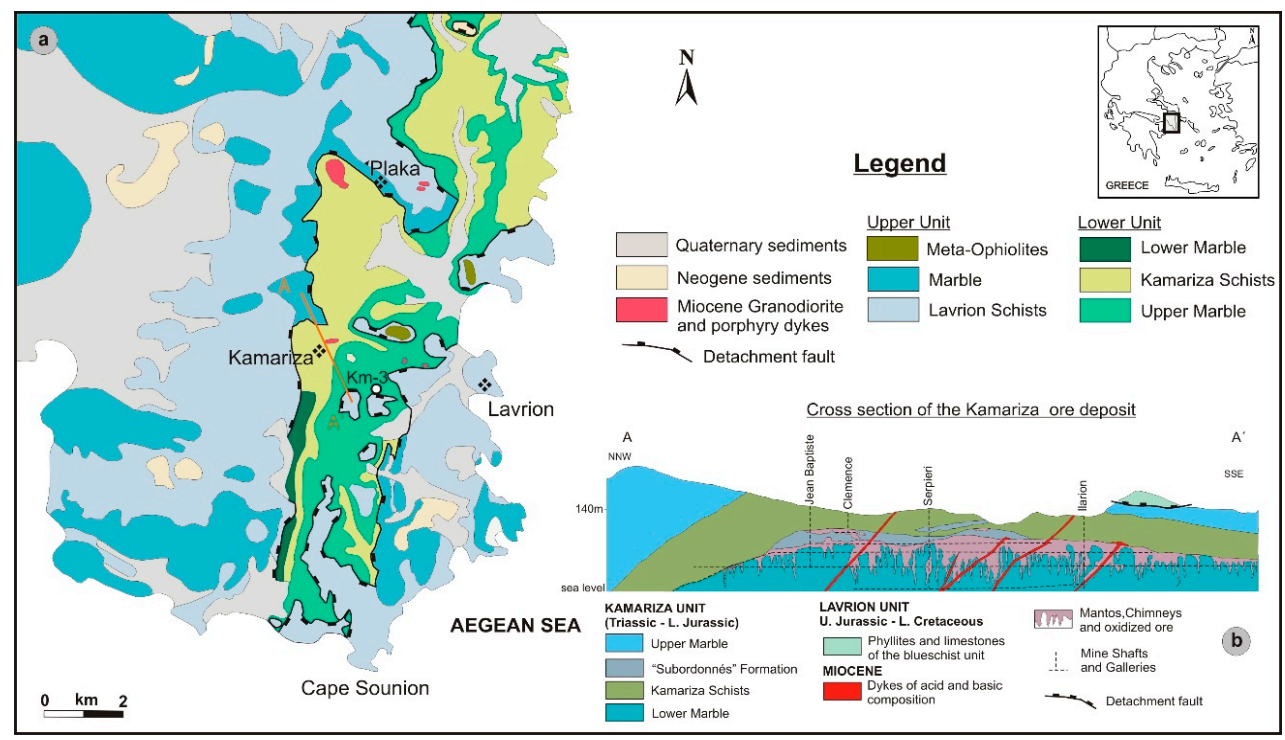

Figure 1. (a) Simplified geological map of the Lavrion ore district; (b) cross-section $\mathrm{A}-\mathrm{A}^{\prime}$ of the Kamariza deposit (modified after Marinos and Petraschek [1] and Scheffer et al. [22]).
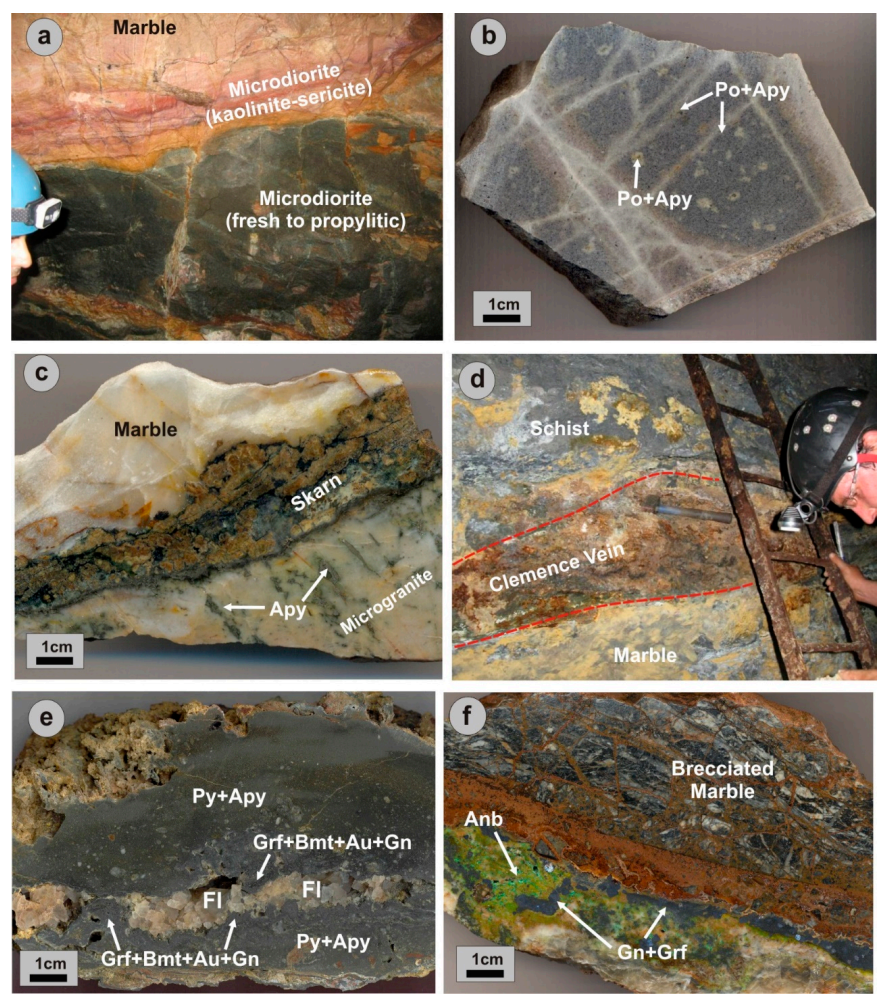

Figure 2. Field photos and hand specimens of granitoids and Ni-bearing ores in the Lavrion district. (a) Propylitic- and kaolinite-sericite-altered microdiorite dike from the Jean Baptiste deposit; (b) carbonate-sericite-quartz veinlets with pyrrhotite (Po) and arsenopyrite (Apy) crosscutting microgranite in the Serpieri mine; (c) skarn mineralization at the contact between microgranite porphyry dike, hosting arsenopyrite (Apy) mineralization, and the lower Kamariza marble; (d) vein-style $\mathrm{Pb}-\mathrm{Zn}$-As-Ni-Au-Bi mineralization between marble and schist from the Clemence mine; (e) hand specimen of banded vein-style mineralization from the Clemence mine, consisting of initial deposition of pyrite (Py) and arsenopyrite (Apy), followed by the deposition of the assemblage of gersdorffite $(\mathrm{Grf})$, bismuthinite (Bmt), gold ( $\mathrm{Au}$ ) and galena $(\mathrm{Gn})$, and finally by the deposition of fluorite (Fl); (f) brecciated marble cemented by galena (Gn) and gersdorffite (Grf) mineralization. The Ni-arsenate annabergite (Anb) is a supergene alteration product of gersdorffite ("km3" deposit). 

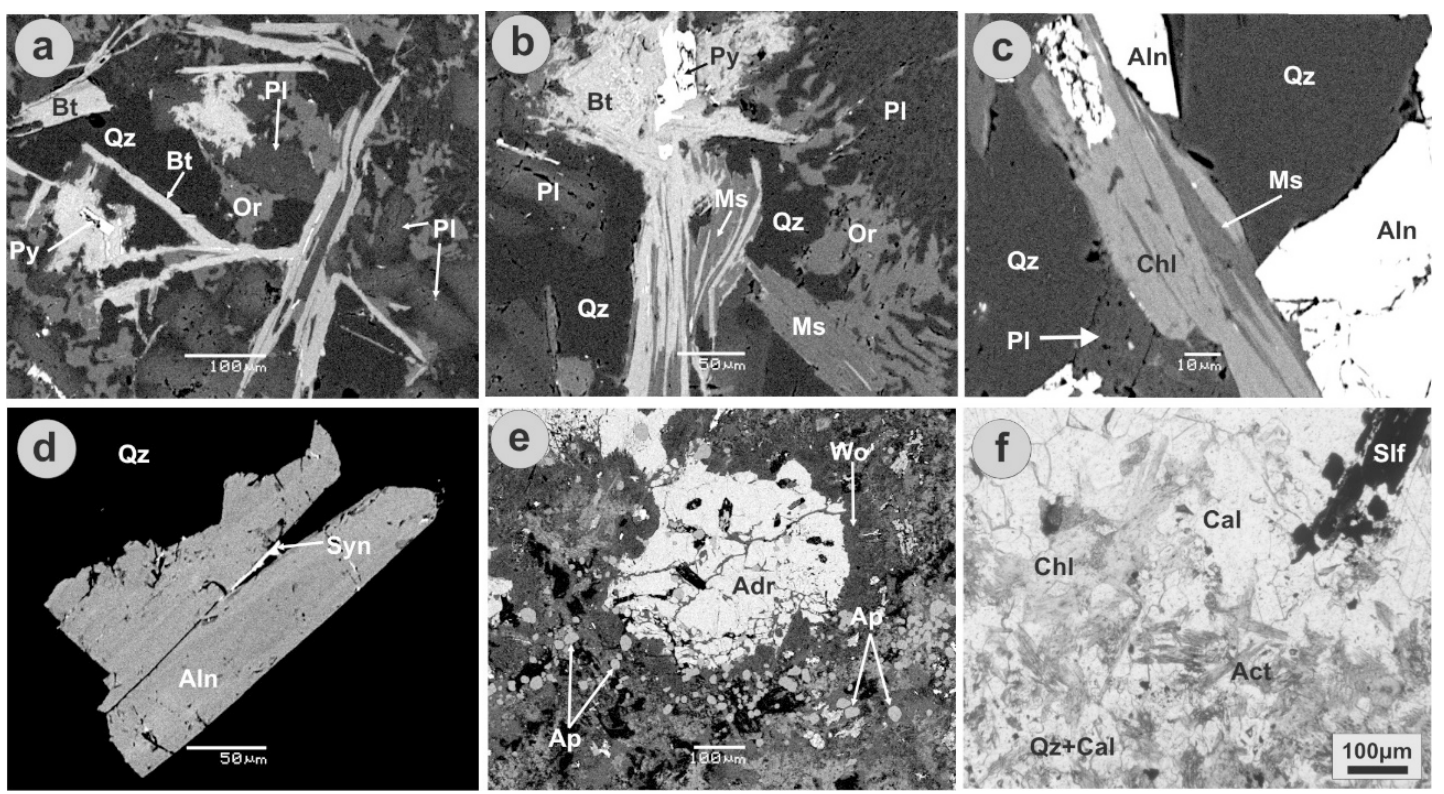

Figure 3. Photomicrographs of silicate assemblages in microgranite and associated skarn mineralization in the Serpieri deposit (a-e): SEM-BSE images; $\mathrm{f}$ : Transmitted, plain-polarized light microphotograph. (a-d) Plagioclase (Pl), biotite (Bt), orthoclase (Or), quartz (Qz), allanite-(Ce) (Aln), and synchysite-(Ce) (Syn) are accompanied by white mica (Ms), pyrite (Py), and chlorite (Chl) (microgranite porphyry); (e) andradite (Adr), wollastonite (Wo), and apatite (Ap) as part of the prograde skarn mineralogy in the Serpieri deposit; (f) quartz, calcite (Cal), chlorite and actinolite (Act) associated with sulfides (Slf) in the retrograde assemblage of the Serpieri skarn.

Table 1. Major (in wt.\%) and trace element content (in ppm) of microgranite porphyry from the Serpieri mine.

\begin{tabular}{cccc}
\hline Sample & S8 & IL $\mathbf{1}$ & S6 \\
\hline $\mathrm{SiO}_{2}$ & 69.29 & 69.61 & 69.41 \\
$\mathrm{TiO}_{2}$ & 0.29 & 0.28 & 0.30 \\
$\mathrm{Al}_{2} \mathrm{O}_{3}$ & 14.87 & 14.62 & 15.01 \\
$\mathrm{Fe}_{2} \mathrm{O}_{3}$ & 2.29 & 2.15 & 1.86 \\
$\mathrm{MnO}$ & 0.02 & 0.03 & 0.02 \\
$\mathrm{MgO}$ & 0.81 & 0.70 & 0.76 \\
$\mathrm{CaO}$ & 3.18 & 2.87 & 2.98 \\
$\mathrm{Na}_{2} \mathrm{O}$ & 3.65 & 3.52 & 3.44 \\
$\mathrm{~K}_{2} \mathrm{O}$ & 3.00 & 3.31 & 2.87 \\
$\mathrm{P}_{2} \mathrm{O}_{5}$ & 0.09 & 0.09 & 0.10 \\
$\mathrm{H}_{2} \mathrm{O}$ & 1.41 & 1.25 & 1.89 \\
$\mathrm{SO}$ & 0.04 & 0.08 & 0.08 \\
$\mathrm{Total}_{\mathrm{Ba}}$ & 98.94 & 98.51 & 98.72 \\
$\mathrm{Ce}$ & 917 & 913 & 895 \\
$\mathrm{Cu}$ & 50 & 56 & 67 \\
$\mathrm{La}$ & 2 & 3 & 6 \\
$\mathrm{Nd}$ & 25 & 25 & 37 \\
$\mathrm{~Pb}$ & 24 & 29 & 29 \\
$\mathrm{Rb}$ & 12 & 17 & 24 \\
$\mathrm{Sr}$ & 85 & 85 & 94 \\
$\mathrm{Zn}$ & 442 & 413 & 419 \\
$\mathrm{Zr}$ & 12 & 12 & 166 \\
& 156 & 162 & 157 \\
\hline
\end{tabular}

In the Serpieri deposit, microgranite dikes are crosscut by porphyry-style sericite-chlorite-calcite \pm quartz stockworks hosting sulfide mineralization consisting of pyrrhotite, arsenopyrite, pyrite, 
and galena (Figures $2 \mathrm{~b}$ and $5 \mathrm{a}, \mathrm{b}$ ). The veinlets are related to carbonate-sericite alteration of the host rock, which overprints secondary biotite and K-feldspar, being part of an earlier potassic alteration event in the system. The skarn occurrence is located along the contact of a microgranitic body and the lower marble of Kamariza (Figure 2c). It is a garnetitic skarn, with andradite, wollastonite, apatite, and magnetite being part of the prograde mineral assemblage (Figure 3e). Calcite, actinolite, epidote, chlorite, quartz, and hematite, as well as pyrite, chalcopyrite, and pyrrhotite formed during the retrograde stage (Figure 3f). Adjacent to the skarn the microgranite is carbonate-sericite altered and contains pyrrhotite and arsenopyrite (Figure 2c).
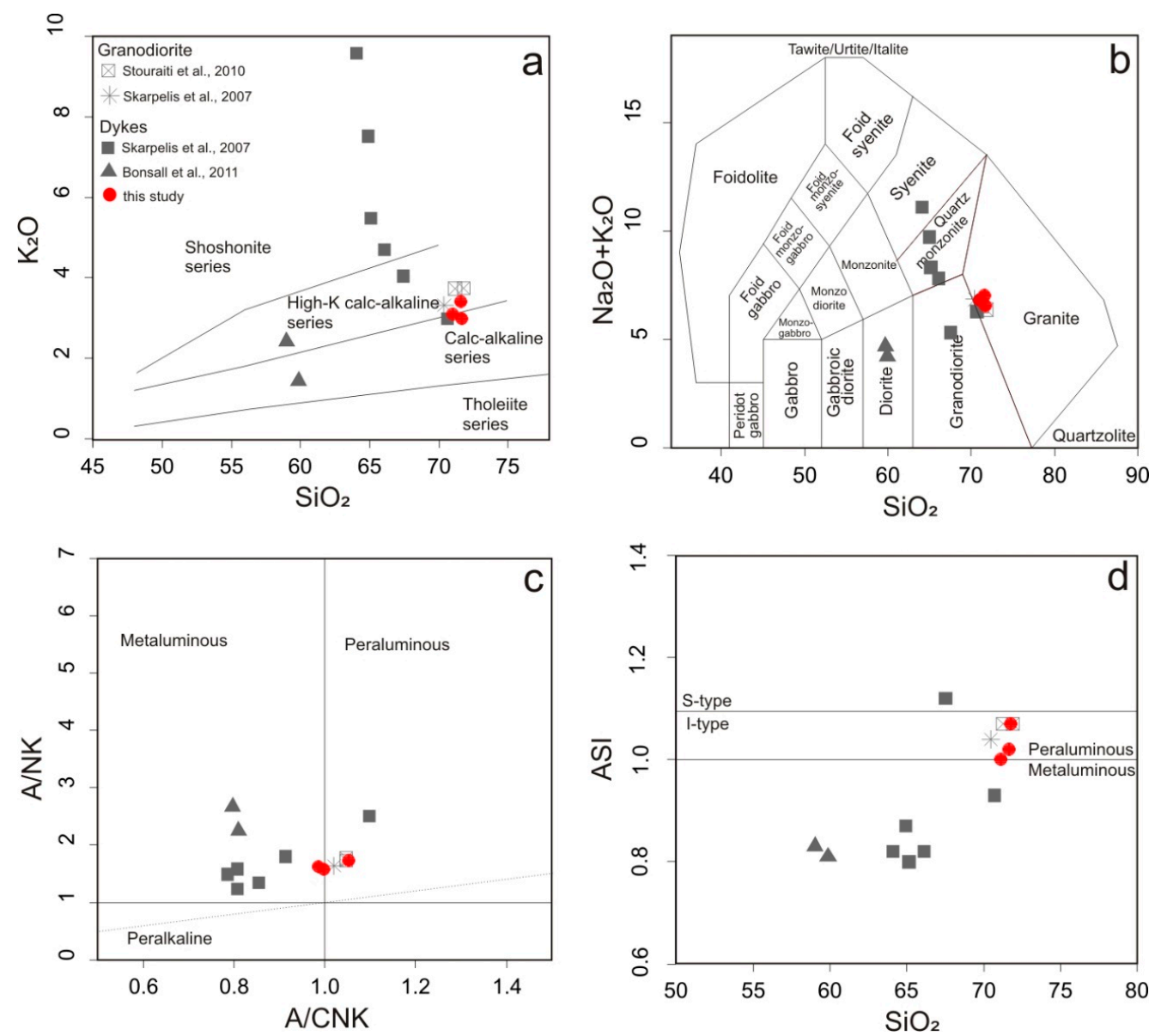

Figure 4. (a) Classification of magmatic rocks in the Lavrion district in terms of $\mathrm{SiO}_{2} \mathrm{vs}_{2} \mathrm{O}$ [25]; (b) total alkali vs. silica diagram of igneous rocks hosting the porphyry-style mineralization in the Serpieri deposit, Kamariza. Rock fields are from Middlemost [26]; (c) A/CNK vs A/NK plot from Shand [27] that discriminates metaluminous, peraluminous, and peralkaline compositions. $\mathrm{A} / \mathrm{NK}=$ molar ratio of $\mathrm{Al}_{2} \mathrm{O}_{3} /\left(\mathrm{Na}_{2} \mathrm{O}+\mathrm{K}_{2} \mathrm{O}\right)$; $\mathrm{A} / \mathrm{CNK}=$ molar ratio of $\mathrm{Al}_{2} \mathrm{O}_{3} /\left(\mathrm{CaO}+\mathrm{Na}_{2} \mathrm{O}+\mathrm{K}_{2} \mathrm{O}\right)$; (d) $\mathrm{ASI}$ vs $\mathrm{SiO}_{2}$ plot discriminating metaluminous, peraluminous and $\mathrm{S}$ - from I-type compositions (after Maniar and Piccoli [28]). ASI = Al/(Ca-1.67P + Na + K). Literature data are from Stouraiti et al. [29], Skarpelis et al. [24] and Bonsall et al. [5].

The nickeliferous assemblage from Clemence mine is composed of vein-type mineralization, which developed at the contact between marbles and schists of the Kamariza unit [4] (Figure 2d). The mineralization also replaced marbles, where it forms extensive manto and chimney bodies. The mineralization in the Clemence vein is characterized by open space filling and mineralogical zonation. Pyrite, arsenopyrite, and sphalerite dominate in the outer parts of the vein, whereas galena and fluorite occur in its center (Figure 2e). Paragenetic relationships in the vein suggest initial deposition of pyrite, arsenopyrite, stannite, and Fe-rich sphalerite, followed by gersdorffite, 
bismuthinite, and native gold, then by chalcopyrite, tennantite/tetrahedrite, bournonite, enargite, and Fe-poor sphalerite, and finally by galena containing exsolved grains and inclusions of semseyite, boulangerite, native antimony, Ag-rich tetrahedrite, stephanite, and miargyrite (Figure $5 c-i$ ). Quartz is the main gangue mineral in the early stage of ore deposition followed by fluorite, the latter of which accompanies galena. In the "km3" district, the nickeliferous assemblage is associated with veins of calcite and galena that crosscut brecciated upper marble of the Kamariza Unit (Figure 5j-1).
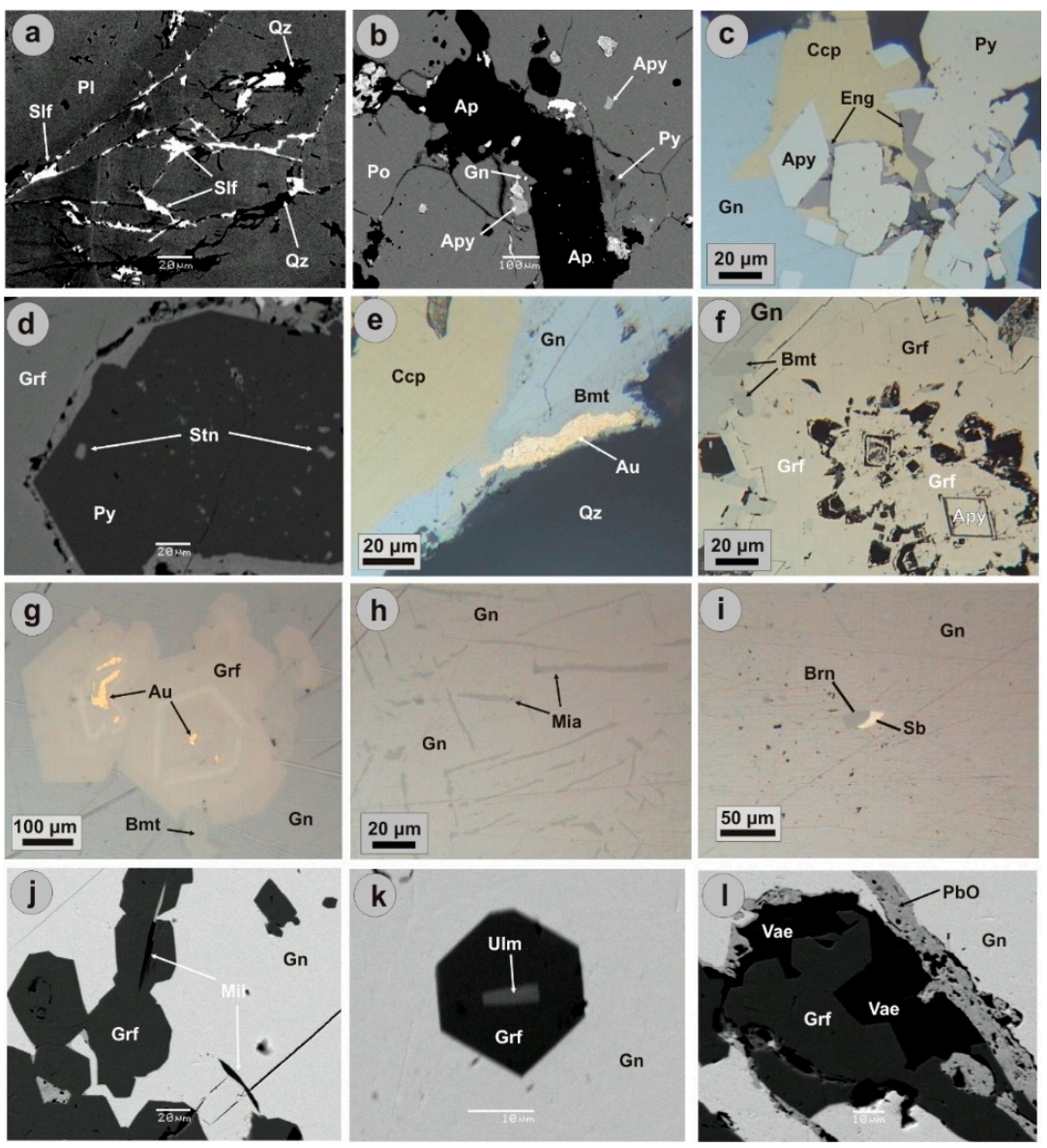

Figure 5. Photomicrographs of the ore parageneses in the Serpieri, Clemence, and "km3" areas. (a) Sulfides (slf) and quartz (Qz) filling fissures in plagioclase (Pl) (KA1, SEM-BSE image, microgranite, Serpieri); (b) pyrrhotite (Po) including arsenopyrite (Apy), pyrite (Py), and galena (Gn). Apatite (Ap) is also present (KA1, SEM-BSE image, microgranite, Serpieri); (c) pyrite and arsenopyrite formed first and were followed by chalcopyrite (Ccp), and enargite (Eng), and then by galena (CLM2, reflected light, plane polarized, Clemence); (d) pyrite with inclusions of stannite (Stn) is surrounded by gersdorffite (Grf) (CLM6a, scanning electron microscope-backscattered image, Clemence); (e) chalcopyrite rimmed by galena and bismuthinite (Bmt), and native gold ( $\mathrm{Au})$. Quartz (Qz) is gangue mineral (CLM6, reflected light, plane polarized, Clemence); (f) arsenopyrite rimmed by gersdorffite, the latter surrounded by bismuthinite and galena (CLM6b, reflected light, plane polarized, Clemence); (g) oscillatory zoned gersdorffite containing native gold and bismuthinite surrounded by galena (CLM6b, reflected light, plane polarized, Clemence); (h) miargyrite (Mia) as exsolution lamellae within galena (CLM4a, reflected light, plane polarized, Clemence); (i) bournonite (Brn) and native antimony ( $\mathrm{Sb}$ ) included in galena (CLM6a, reflected light, plane polarized, Clemence); (j) millerite (Mil) needles included in gersdorffite and galena (scanning electron microscope-backscattered electron image, "km3"); (k) ullmannite (Ulm) enclosed in gersdorffite (scanning electron microscope-backscattered image, "km3"); (1) gersdorffite surrounded by vaesite (Vae), enclosed in galena (Gn) (scanning electron microscope-backscattered image, "km3"). 


\section{Bulk Ore Geochemistry}

Bulk analyses of Clemence ore reveal $\mathrm{Au}$ and $\mathrm{Ag}$ grades exceeding $100 \mathrm{~g} / \mathrm{t}, \mathrm{Pb}$ and $\mathrm{Zn}>1 \mathrm{wt.} \%$, Ni up to 9700 ppm, Co up to 118 ppm, Sn > 100 ppm, and Bi > 2000 ppm (Table 1). Mineralization at "km3" is enriched in Mo (up to $36 \mathrm{ppm}$ ), As and Ni (both >1 wt.\%), and Co (up to $1290 \mathrm{ppm}$ ), whereas other elements occur in lesser amounts: Te (up to $2 \mathrm{ppm}$ ), Sn (up to $8.5 \mathrm{ppm}$ ), and Bi (up to $1.3 \mathrm{ppm}$ ). Preliminary data on sericite altered dikes and sills indicate enrichment in Ni (up to $220 \mathrm{ppm}$ ), $\mathrm{Cu}$ (up to $175 \mathrm{ppm}$ ), As (up to $510 \mathrm{ppm}$ ), Mo (up to $6 \mathrm{ppm}$ ), and $\mathrm{Pb}$ (up to $830 \mathrm{ppm}$ ) (Table 2).

Table 2. Trace element content (in ppm) of mineralization in the Clemence (CLM-series) and "km3"

(Km3-series) deposits, and porphyry-style mineralized Serpieri (S-series) dikes. bd = below detection.

\begin{tabular}{ccccccccccccccc}
\hline & $\mathbf{M o}$ & $\mathbf{C u}$ & $\mathbf{A u}$ & $\mathbf{A g}$ & $\mathbf{P b}$ & $\mathbf{Z n}$ & $\mathbf{A s}$ & $\mathbf{S b}$ & $\mathbf{N i}$ & $\mathbf{C o}$ & $\mathbf{T e}$ & $\mathbf{S n}$ & $\mathbf{B i}$ & $\mathbf{C d}$ \\
\hline CLM-1 & 0.26 & 5869 & 0.04 & $>100$ & $>10,000$ & 536 & $>10,000$ & $>2000$ & 3.1 & 14.7 & 1.63 & 28.4 & 93.9 & 12.1 \\
CLM-2 & 0.25 & 3485 & 0.10 & $>100$ & $>10,000$ & 1129 & $>10,000$ & $>2000$ & 11.6 & 42.7 & 1.48 & 27 & 85.2 & 9.35 \\
CLM-3 & 0.11 & 323 & 0.04 & $>100$ & $>10,000$ & $>10,000$ & 4952 & 1554 & 1.1 & 83.9 & 1.51 & 25.1 & 12.4 & 304 \\
CLM-4 & 1.90 & 45.1 & bd & 7.97 & 1441 & 324 & 1338 & 62 & 8.9 & 92.2 & 0.03 & 0.9 & 0.74 & 3.87 \\
CLM-6 & 0.31 & 2503 & $>100$ & $>100$ & $>10,000$ & 326 & $>10,000$ & $>2000$ & 9686 & 118 & 1.26 & 16.4 & $>2000$ & 14.6 \\
CLM-6B & 0.26 & $>10,000$ & 3.80 & $>100$ & $>10,000$ & $>10,000$ & 7983 & $>2000$ & 388 & 80.4 & 1.34 & $>100$ & 133 & 171 \\
Km3-1 & 4.31 & 933 & 0.08 & $>100$ & $>10,000$ & 4195 & $>10,000$ & $>2000$ & $>10,000$ & 207 & 1.73 & 8.3 & 1.29 & 15.5 \\
Km3-2 & 35.8 & 45.2 & 0.02 & $>100$ & $>10,000$ & 1591 & $>10,000$ & $>2000$ & $>10,000$ & 175 & 2.10 & 5.7 & 0.81 & 4.09 \\
Km3-3 & 11.7 & 88.9 & 0.08 & $>100$ & $>10,000$ & 864 & $>10,000$ & $>2000$ & $>10,000$ & 231 & 2.25 & 8.1 & 1.18 & 5.06 \\
S-1 & 5.62 & 175 & 0.02 & 0.07 & 10.7 & 145 & 431 & 1.21 & 0.4 & 20.6 & 1.76 & 3.1 & 4.38 & 0.43 \\
S-3 & 0.19 & 29.8 & 0.03 & 0.04 & 15 & 79.6 & 410 & 0.72 & 1.3 & 21.3 & 0.24 & 0.3 & 0.26 & 0.13 \\
S-5 & 0.49 & 15.4 & 0.03 & 1.22 & 831 & 26.2 & 512 & 14.4 & 219 & 41.7 & 0.08 & 0.4 & 0.14 & 0.19 \\
S-8b & 2.82 & 18.8 & 0.01 & 0.03 & 110 & 69.3 & 8.8 & 12.8 & 0.8 & 68.5 & $<0.02$ & 0.7 & 0.17 & 0.41 \\
S-9 & 0.88 & 30.8 & 0.03 & 0.09 & 38.4 & 136 & 15.2 & 0.76 & 6.2 & 51.9 & $<0.02$ & 0.4 & 0.11 & 0.19 \\
S-11 & 5.37 & 74.2 & 0.05 & 0.25 & 32.8 & 166 & 121 & 0.77 & 2.9 & 15.7 & 0.14 & 3.7 & 0.87 & 0.18 \\
\hline
\end{tabular}

\section{Ore Mineralogy}

Previous work by Voudouris et al. [4] described the mineralogy and mineral chemistry of metallic minerals from the Clemence deposit in detail. Additional information is given here: in summary, pyrite (Figure $5 \mathrm{c}, \mathrm{d}$ ) has $\mathrm{Co}$ and $\mathrm{Ni}$ contents below detection limits. It includes small grains of stannite $\left(\mathrm{Cu}_{2} \mathrm{FeSnS}_{4}\right)$ (Figure $5 \mathrm{~d}$ ). Arsenopyrite contains 41.10 to $43.15 \mathrm{wt} . \%$ As, which corresponds to $29.90-31.06$ atomic \% As. Early sphalerite is Fe-rich (up to 24.7 mole \% FeS) and associated with arsenopyrite, whereas late sphalerite is Fe-poor $(2.9$ mole $\% \mathrm{FeS})$ and associated with the $\mathrm{Cu}$-As-bearing association that includes chalcopyrite, tennantite, and enargite. Galena contains inclusions of gersdorffite, semseyite, bismuthinite, bournonite, native antimony, and native gold (Figure 5e-i). It also contains exsolved grains of boulangerite, Ag-rich tetrahedrite, stephanite $\left(\mathrm{Ag}_{5} \mathrm{SbS}_{4}\right)$, and miargyrite $\left(\mathrm{AgSbS}_{2}\right)$ (Figure $\left.5 \mathrm{~h}\right)$. Bismuthinite is included in gersdorffite and galena (Figure $5 \mathrm{e}-\mathrm{g}$ ). Native gold commonly forms grains up to $150 \mu \mathrm{m}$ in size enclosed in gersdorffite, but can also be found as intergrowths with bismuthinite and/or as isolated grains enclosed in galena (Figure 5e,g). It contains 11.50 to $18.56 \mathrm{wt}$ \% Ag [2]. Gersdorffite occurs as zoned idiomorphic crystals enclosed in galena, and as rims on pyrite and arsenopyrite (Figure $5 \mathrm{~d}$,f). It displays oscillatory zoning in terms of $\mathrm{Fe}, \mathrm{Ni}$, and As content, varying from 1.5 to $9.0 \mathrm{wt} . \%, \sim 24$ to $32 \mathrm{wt} . \%$ and 47 to $60 \mathrm{wt} . \%$, respectively (Table 2, Figures 6 and 7). There is an almost perfect linear correlation between Fe-Ni and As-S in the gersdorffite structure (Figure 7c,d). Gersdorffite from the Clemence deposit contains up to $0.2 \mathrm{wt} . \% \mathrm{Se}$, which likely substitutes for sulfur in the structure. At the "km3" locality, gersdorffite contains $\sim 0.5-2$ wt.\% Fe, 46-48 wt.\% As, and $\sim 31-34$ wt.\% Ni (Table 2). Millerite (NiS) is found in association with gersdorffite as small inclusions or as euhedral needle-shaped crystals enveloped by galena (Figure 5j). As-bearing ullmannite, $\mathrm{Ni}(\mathrm{Sb}, \mathrm{As}) \mathrm{S}$, occurs as inclusions in gersdorffite (Figure 5k), whereas vaesite $\left(\mathrm{NiS}_{2}\right.$ ) rims gersdorffite (Figure 51 ). Cobalt (of up to $0.35 \mathrm{wt} . \%$ ) substitutes for $\mathrm{Ni}$ in vaesite and millerite (Table 3 ). 


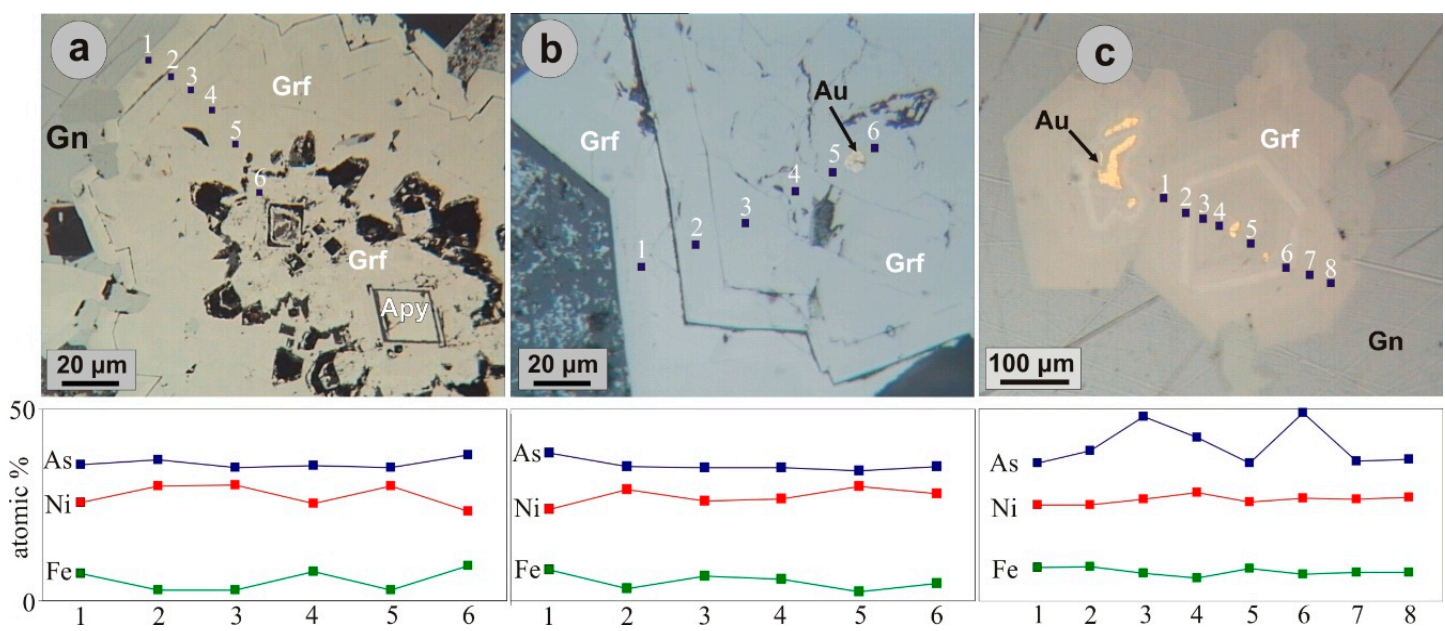

Figure 6. Electron probe microanalyses line scans of As, Ni, Fe distribution along traverses in gersdorffite.
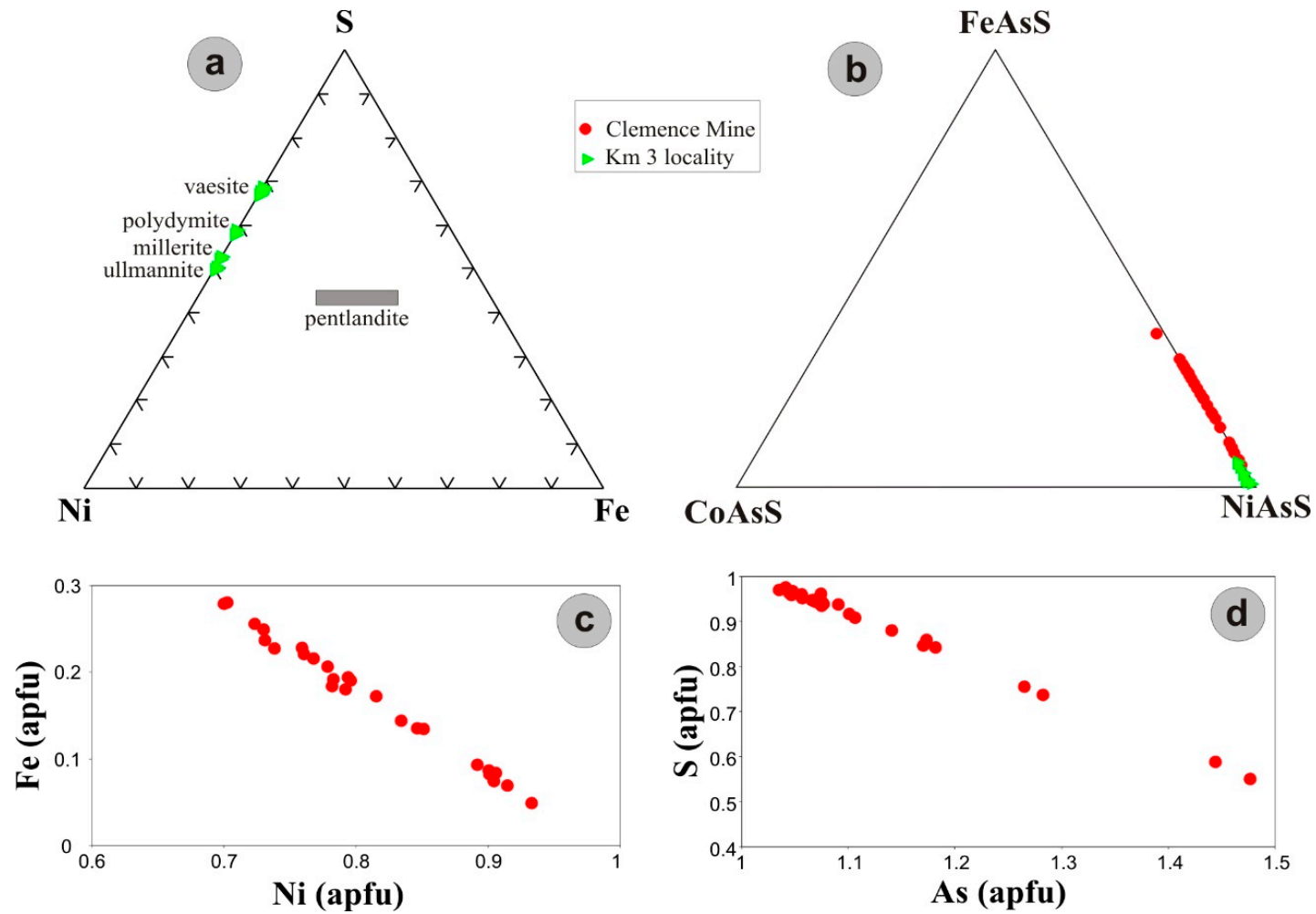

Figure 7. Chemical variation of Ni sulfides/sulfarsenides from Lavrion: $(\mathbf{a}, \mathbf{b})$ Ternary plots in terms of $\mathrm{Ni}, \mathrm{Fe}, \mathrm{S}$ and $\mathrm{Ni}, \mathrm{Fe}, \mathrm{Co}$, respectively; (c,d) Fe vs $\mathrm{Ni}$ and As vs $\mathrm{S}$ plots. 
Table 3. Representative electron microprobe analyses of gersdorffite (1-8: Clemence Mine; 9,10: “km-3"), vaesite $(11,12)$, millerite $(13,14)$; polydymite $(15,16)$; ullmannite $(17,18)$. bd: below detection limit, na: not analyzed; apfu: atoms per formula unit.

\begin{tabular}{|c|c|c|c|c|c|c|c|c|c|c|c|c|c|c|c|c|c|c|}
\hline wt. \% & 1 & 2 & 3 & 4 & 5 & 6 & 7 & 8 & 9 & 10 & 11 & 12 & 13 & 14 & 15 & 16 & 17 & 18 \\
\hline $\mathrm{Ni}$ & 24.12 & 26.81 & 32.04 & 28.67 & 25.00 & 27.59 & 25.04 & 25.22 & 34.55 & 32.65 & 46.19 & 45.93 & 63.18 & 62.48 & 56.42 & 56.67 & 28.00 & 27.71 \\
\hline $\mathrm{Fe}$ & 9.10 & 7.59 & 2.23 & 5.70 & 8.06 & 4.46 & 5.54 & 5.40 & 0.49 & 1.63 & 0.37 & 0.05 & 0.54 & 0.20 & 0.16 & 0.38 & 0.02 & 0.11 \\
\hline Co & bd & $\mathrm{bd}$ & bd & $\mathrm{bd}$ & bd & bd & bd & bd & 0.13 & bd & 0.18 & 0.35 & 0.06 & 0.26 & bd & bd & bd & bd \\
\hline As & 50.12 & 47.55 & 46.26 & 47.84 & 51.61 & 54.07 & 58.96 & 59.95 & 46.99 & 47.55 & 0.97 & 0.09 & 0.45 & 0.16 & bd & bd & 8.41 & 8.88 \\
\hline $\mathrm{Sb}$ & 0.08 & bd & 0.78 & 0.10 & bd & 0.13 & 0.04 & 0.02 & na & na & na & na & na & na & bd & bd & 47.93 & 46.72 \\
\hline $\mathrm{Bi}$ & bd & bd & 0.18 & bd & bd & 0.05 & bd & bd & na & na & na & na & na & na & na & na & na & na \\
\hline Total & 100.18 & 100.54 & 100.26 & 100.64 & 100.59 & 100.01 & 100.34 & 100.60 & 100.88 & 100.82 & 100.36 & 100.02 & 100.61 & 99.42 & 99.97 & 99.40 & 101.11 & 98.84 \\
\hline apfu & 3 & 3 & 3 & 3 & 3 & 3 & 3 & 3 & 3 & 3 & 3 & 3 & 2 & 2 & 7 & 7 & 3 & 3 \\
\hline $\mathrm{Ni}$ & 0.700 & 0.759 & 0.915 & 0.816 & 0.730 & 0.835 & 0.782 & 0.792 & 0.975 & 0.918 & 0.962 & 0.955 & 0.967 & 0.963 & 2.902 & 2.943 & 0.977 & 0.977 \\
\hline $\mathrm{Fe}$ & 0.278 & 0.226 & 0.067 & 0.170 & 0.247 & 0.142 & 0.182 & 0.178 & 0.016 & 0.048 & 0.008 & 0.001 & 0.008 & 0.003 & 0.009 & 0.021 & 0.000 & 0.000 \\
\hline Co & 0.000 & 0.000 & 0.000 & 0.000 & 0.000 & 0.000 & $\mathrm{Bd}$ & 0.000 & 0.003 & 0.000 & 0.003 & 0.002 & 0.001 & 0.004 & 0.000 & 0.000 & 0.000 & 0.000 \\
\hline $\mathrm{Au}$ & 0.001 & 0.000 & 0.001 & 0.001 & 0.001 & 0.002 & 0.003 & 0.003 & - & - & - & - & - & - & - & - & - & - \\
\hline
\end{tabular}

\section{Discussion}

The genesis of the $\mathrm{Pb}-\mathrm{Zn}-\mathrm{Ni}-\mathrm{As}-\mathrm{Bi}-\mathrm{Au}$ and the $\mathrm{Pb}-\mathrm{Ni}-\mathrm{Co}-\mathrm{As}-\mathrm{Mo}-\mathrm{Ag}$ associations from the Clemence and "Km3" deposits, respectively, is still a matter of debate. Both styles of mineralization share some similarities with the so-called "five element" deposits that are characterized by the elemental association Ag-Ni-Co-As-Bi $\pm \mathrm{U}$ [30,31]. The characteristic feature of these deposits is the presence of native silver in association with $\mathrm{Ni}-\mathrm{Co}-\mathrm{Fe}-\mathrm{Sb}$ sulfarsenides, and Ni-Co-Fe arsenides, with the best examples containing the element association Ag-Ni-Co. In some respects, there are some common features of the studied mineralization and the five elements association but there are differences, including the absence of dendritic native silver and bismuth. The Kamariza veins are $\mathrm{Pb}-\mathrm{Zn}-\mathrm{Cu}$-dominant and contain relatively little Ag-Bi-Co. Therefore, they do bear some resemblance to, but are not, classical five element veins.

A magmatic contribution for metals in the Lavrion area was proposed by Voudouris et al. [4] and Bonsall et al. [5], mainly based on the close spatial relationship of the deposits with porphyritic dikes of granodioritic to andesitic composition. A genetic relationship between nickel sulfides and sulfarsenides, native bismuth, bismuthinite, pyrrhotite, and precious metals ( $\mathrm{Au}, \mathrm{Ag})$ with granitoid intrusions was reported previously from several ore deposits (e.g. Ulsan Fe-W deposit in S. Korea [32], Cradock in South Africa [33] and Erzgebirge, Germany [34]). For the multi-stage Ag-Bi-Co-Ni-U and Cu-Bi vein mineralization at Wittichen, Schwarzwald, SW Germany, which consists of Ni sulfarsenides, native Bi and various Bi sulfosalts, Staude et al. [35] suggested a granitic source for the occurrence of Bi in all stages and leaching from the host rock (redbeds) of some ore-forming elements (e.g. Ag, Co and Ni) at temperatures from around 300 to $<100{ }^{\circ} \mathrm{C}$. Remobilization and leaching of Co, Ni, Fe, and As from mafic/ultramafic wall rocks was favoured for the ore at Bou Azzer, Morocco [36] and Cobalt, Ontario, Canada [37]. However, at Bou Azzer, where no Bi-bearing minerals were reported, acidic magmatic fluids under moderately reducing conditions at high fluid/rock ratios leached $\mathrm{Co}, \mathrm{Ni}, \mathrm{Fe}$, and As from serpentinites [36]. At the neighboring Imiter Ag-Hg deposit, Morocco, Essaraj et al. [38] distinguished two mineralizing events: The first is related to magmatic intrusions and comprises uneconomic Co-Ni-As ores that were superimposed by an economic, Ag-rich mineralization, deposited by basinal brines, which leached the metals from the basement rocks. Similarly, the likely source of $\mathrm{Ni}$ and $\mathrm{Au}$ in the $\mathrm{Ni}-\mathrm{Sb}-\mathrm{Ag}-\mathrm{Au}$ association, as exemplified by the presence of ullmannite, allargentum, Au-rich silver, and Au-bearing dyscrasite, from the Kutná Hora Pb-Zn-Ag ore district (Czech Republic), was the serpentinized ultramafic bodies, which were cut by the "silver" lodes in the south of the ore district [39]. The scenario of remobilization and leaching of metals from previous mineralization 
and/or host rocks, including the metabasite boudins found in the Lavrio schists, through the late involvement of non-magmatic fluid in the ore system, was recently favoured by Scheffer et al. [40], for at least the $\mathrm{Pb}-\mathrm{Zn}$-Ag vein-style mineralization in the Lavrion district.

Oscillatory zoning is common in sulfides (e.g. pyrite, arsenopyrite, sphalerite, molybdenite and fahlores) [41-43]. Oscillatory zoning in gersdorffite was reported from the San Juan de Plan deposit, Spain [44], the high-grade Ni-Co-Fe-As hydrothermal vein ores from Dobšiná (Slovakia) [45], and from $\mathrm{Pb}-\mathrm{Ag}-\mathrm{Zn}$ deposits within the Rogozna ore field, Serbo-Macedonian metallogenic province [46]. The oscillatory variations in $\mathrm{As}, \mathrm{Ni}$, and $\mathrm{Fe}$ content of individual micro-zones observed within the Clemence gersdorffite suggest physical or chemical fluctuations within the bulk system and disequilibrium in the ore fluids [47].

On the basis of arsenopyrite composition (30.8 to 32.7 at. \% As) for the pyrite-arsenopyrite assemblage at the Clemence deposit, a temperature range of $400-450{ }^{\circ} \mathrm{C}$ is deduced at $f S_{2}=10^{-6}$ to $10^{-8}$ atm, using the calibrations of Kretschmar and Scott [48] and Sharp et al. [49] (shaded area, Figure 8a). It should be mentioned that the arsenopyrite geothermometer of Kretschmar and Scott [48] may overestimate temperatures when compared to those derived from fluid inclusion data, and underestimates sulfur fugacity since, according to the work of Sharp et al. [49], it is also a function of pressure. However, the lower limit of this temperature range is in accordance with the early quartz in the Kamariza district, which crystallized between 300 and $400{ }^{\circ} \mathrm{C}$ [4]. These temperatures are in agreement with those recorded during post-orogenic exhumation and mark the ductile-brittle transition [21,22]. Fluid inclusions in fluorite from the Clemence deposit associated with galena and homogenized at between 233 and $275^{\circ} \mathrm{C}$ [4]. It is suggested here that the initial ore deposition at Clemence took place at about 350 to $400{ }^{\circ} \mathrm{C}$ at $\log f S_{2}=-10$ to -8 . This range of temperature and $f S_{2}$ corresponds to deposition of pyrite-arsenopyrite-gersdorffite in equilibrium with Fe-rich sphalerite within the stability field of bismuthinite and native gold, and then by a decrease in the Fe content of sphalerite from about 25 to $3 \mathrm{~mol} \% \mathrm{FeS}$, and by the deposition of enargite (arrow, Figure 8b). A subsequent path of decreasing temperature (from about 350 to $200^{\circ} \mathrm{C}$ ) probably occurs along the tennantite-enargite/luzonite boundary with contemporaneous deposition of galena (Figure 8b).

Previous work by Voudouris et al. [4] suggested that the association between bismuthinite and native gold in the gold-bearing galena ores within the Clemence deposit may have been caused by the sulfidation of maldonite in response to an increase in $f S_{2}$, and that the presence of sulfarsenide minerals associated with native gold and bismuthinite from reduced hydrothermal fluids. If this was the case, maldonite should be part of a very early low-sulfidation and strongly reduced assemblage in the Kamariza district, in the stability field of pyrrhotite, arsenopyrite and/or löllingite (all three phases are present in Kamariza ore). Maldonite was not observed as part of the present study, although its presence in Lavrion ore was reported in association with native bismuth and native gold by Wendel and Markl [8] and Rieck [52]. However, Solomos et al. [3] argued for a contemporaneous deposition of chalcopyrite with bismuthinite, native bismuth, and maldonite (which was later decomposed to native gold and native bismuth) for oxidized Au-Bi ores in the Ilarion deposit in the Kamariza district. Native gold also occurs as isolated grains within galena but not in contact with bismuthinite, thus suggesting that the hydrothermal fluids were probably buffered along the boundary $A u+\mathrm{Bi}_{2} \mathrm{~S}_{3} / \mathrm{Au}_{2} \mathrm{Bi}$ during gold deposition.

The discovery of a new, previously unknown skarn and porphyry-style mineralization in the Kamariza district gives new information on the origin of the sulfide mineralization in the Lavrion district. It also allows for a direct comparison with the major skarn and porphyry deposits of the neighboring Plaka area, since both skarn occurrences contain pyrrhotite, pyrite, and magnetite. Sulfide and oxide mineralogy are used to constrain $f \mathrm{O}_{2}$ and $f \mathrm{~S}_{2}$ values of hydrothermal solutions during the evolution of the Serpieri skarn-porphyry style mineralization at $400{ }^{\circ} \mathrm{C} / 0.5 \mathrm{~kb}$ and $275{ }^{\circ} \mathrm{C}$ (vapor saturation), in accordance with the temperatures estimated by fluid inclusion temperatures determined by Voudouris et al. [4] for the Kamariza district (Figure 8c,d). Early-stage skarn and contemporaneous porphyry-style mineralization formed at around $400{ }^{\circ} \mathrm{C} / 0.5 \mathrm{~kb}$ at $\log f \mathrm{~S}_{2}=-8$ and -7 and $\log f \mathrm{O}_{2}=-27$ 
(Figure 8c). These values are consistent with the stability of the assemblage magnetite-pyrite-pyrrhotite in the ore system. During the retrograde stage of mineralization (e.g. at $\sim 275^{\circ} \mathrm{C}$ ), the $\log f \mathrm{~S}_{2}=-11$ and -9 and $\log f \mathrm{O}_{2}=-33$ to -31 are constrained by the stabilities of pyrite, chalcopyrite, hematite, and galena (Figure $8 \mathrm{~d}$ ).
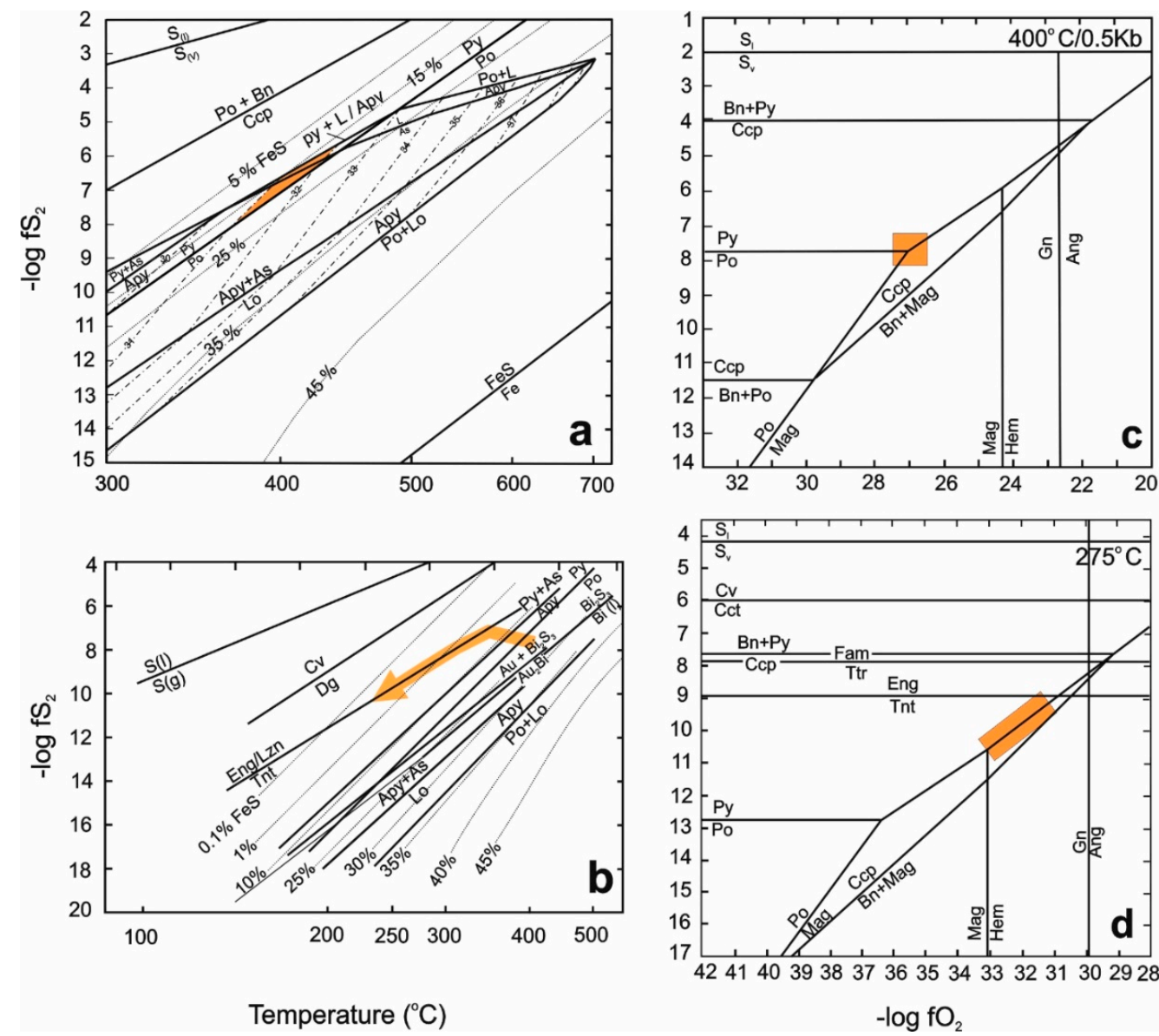

Figure 8. (a,b) $\log f \mathrm{~S}_{2}-\mathrm{T}$ diagrams showing sulfidation reactions and hypothetical conditions of formation of the Clemence Ni-Au-Bi mineralization. The mineral stability field in the Fe-As-S system, as well as the isopleth contours of As in arsenopyrite (at. \%; dash-dotted lines) in equilibrium with vapor, were derived from Kretschmar and Scott [48] and Sharp et al. [49]. The iron content in sphalerite (moles \% FeS; dotted lines) is drawn according to the data of Scott and Barnes [50]. Stability fields of native bismuth/bismuthinite and native gold + bismuthinite/maldonite and other sulfidation reactions involving sulfides, sulfarsenides, sulfosalts and native elements were derived from Barton and Skinner [51]. The conditions of formation during the precipitation of arsenopyrite and pyrite are indicated by the shaded area in Figure 5c. An evolution towards higher sulfur fugacities and then along the enargite/tennantite boundary with decreasing temperatures is indicated by the arrow in Figure 5 b. (c,d) $\log f \mathrm{~S}_{2}-\log f \mathrm{O}_{2}$ diagrams indicating equilibria among sulfides, oxides, and silicates at (c) $400{ }^{\circ} \mathrm{C} / 0.5 \mathrm{~kb}$ and (d) $275{ }^{\circ} \mathrm{C}$ and vapor saturation for the prograde and retrograde skarn assemblages at Kamariza. The shaded area indicates approximate conditions of skarn formation. Abbreviations: Apy = arsenopyrite, $\mathrm{Bn}=$ bornite, $\mathrm{Ccp}=$ chalcopyrite, $\mathrm{Cct}=$ chalcocite, $\mathrm{Cv}=$ covellite, Eng = enargite, Fam = famatinite, Hem = hematite, L = liquid, Lol = löllingite, Mag = magnetite, Po $=$ pyrrhotite, $\mathrm{Py}=$ pyrite, $\mathrm{Tnt}=$ tennantite, $\mathrm{Ttr}=$ tetrahedrite, $\mathrm{Sl}=$ sulfur liquid, $\mathrm{Sv}=$ sulfur vapor.

This study suggests that both the Kamariza skarn and the associated microgranites (porphyry-style veinlets) are mineralized with base metal sulfides (e.g. pyrite, chalcopyrite, pyrrhotite, arsenopyrite, sphalerite and galena), which is the same metallic mineral assemblage that characterizes the manto- and vein/breccia-style mineralization in the Lavrion district. Carbonate-replacement 
mineralization is especially enriched close to the contacts between dikes and the surrounding marbles and schists. It is suggested here that these intrusive bodies fed the deposit with metals and volatiles, as has been proposed previously [2-5].

In the "km3" district, deposition of Ni sulfides was followed by formation of gersdorffite, the presence of which indicates an increase in the As content and a decrease in the Ni activity of the hydrothermal fluid. Late galena associated with fluorite rims gersdorffite in both the Clemence deposit and "km3" district, demonstrating a common fluid evolution along the detachment system in the Lavrion district.

\section{Conclusions}

The famous Lavrion $\mathrm{Pb}-\mathrm{Zn}$-Ag-Au district hosts several Ni-Bi-Pb-bearing deposits that formed synchronously with the intrusion of a Miocene granodiorite body and related felsic and mafic dikes and sills within marbles and schists of the Attic-Cycladic blueschists. At the Seprieri deposit (Kamariza district), a porphyry-style pyrrhotite-arsenopyrite mineralized granitic sill/dike is genetically related to a garnet- and wollastonite-bearing mineralized skarn characterized by base metal sulfides and enriched in Mo, Sn, and Ni. At the neighboring Clemence deposit, oscillatory zoned gersdorffite is associated with native gold and bismuthinite within a vein-type $\mathrm{Pb}-\mathrm{Ni}-\mathrm{Bi}-\mathrm{Au}-\mathrm{Ag}$ mineralization, which contains arsenopyrite, pyrite, chalcopyrite, tennantite, enargite, and galena. Variable As, Ni, and Fe contents in gersdorffite indicate fluctuations in arsenic and sulfur fugacities in the hydrothermal fluid. An evolution towards higher sulfur fugacity in the mineralization is evident by the late deposition of enargite in the ore system. Gersdorffite-bearing ore from "km3" is associated with vaesite, millerite, ullmannite, and polydymite, enclosed in galena. Our data further support a magmatic contribution to the ore-forming fluids, although remobilization and leaching of metals from previous mineralization and/or host rocks, through the late involvement of non-magmatic fluid in the ore system, cannot be excluded.

Author Contributions: P.V., B.R., and U.K. collected the studied samples; P.V., assisted by C.M., P.S., E.G., and S.Z., evaluated the mineralogical data; C.S., A.T., O.V., V.M., K.S., and A.F. evaluated the geochemical and structural data; P.V., C.M., E.G., and P.S. wrote the manuscript.

Funding: This research was partly funded by LABEX Ressources21, Nancy, France.

Acknowledgments: The authors would like to thank Evangelos Michailidis and Stefanie Heidrich for their kind help on microanalyses in the National and Kapodistrian University of Athens and Institute of Mineralogy-Petrology, University of Hamburg, respectively. Dave Lentz and an anonymous reviewer are especially thanked for their constructive comments that greatly improved the manuscript. This paper is an extended version of a manuscript entitled "The Ni-Bi-Au association at Kamariza and "km-3", Lavrion ore district, Greece", which was submitted in the 1st Electronic Conference on Mineral Science, Sciforum, 2018. The authors dedicate this article to the memory of our good friends, Alkiviadis Tsolakos and Christos Solomos, who greatly contributed to the knowledge of underground Lavrion.

Conflicts of Interest: The authors declare no conflict of interest.

\section{References}

1. Marinos, G.; Petrascheck, W.E. Laurium. Geological and geophysical research. Greece Inst. Geol. Subsurf. Res. 1956, 4, 1-247.

2. Voudouris, P.; Economou-Eliopoulos, M. Mineralogy and chemistry of Cu-rich ores from the Kamariza carbonate-hosted deposit (Lavrion), Greece. In Exploration and Sustainable Development; Millpress: Rotterdam, The Netherlands, 2003; pp. 499-502.

3. Solomos, C.; Voudouris, P.; Katerinopoulos, A. Mineralogical studies of a bismuth-gold-antimony mineralization in Kamariza, Lavrion. Bull. Geol. Soc. Greece 2004, 36, 387-396, (In Greek with English Abstract). [CrossRef]

4. Voudouris, P.; Melfos, P.; Spry, P.G.; Bonsall, T.A.; Tarkian, M.; Solomos, C. Carbonate-replacement Pb-Zn-Ag $\pm \mathrm{Au}$ mineralization in the Kamariza area, Lavrion, Greece: Mineralogy and thermochemical conditions of formation. Mineral. Petrol. 2008, 94, 85-106. [CrossRef] 
5. Bonsall, T.A.; Spry, P.G.; Voudouris, P.; Seymour, K.S.; Tombros, S.; Melfos, V. The geochemistry of carbonate-replacement $\mathrm{Pb}-\mathrm{Zn}-\mathrm{Ag}$ mineralization in the Lavrion district, Attica, Greece: Fluid inclusion, stable isotope, and rare earth element studies. Econ. Geol. 2011, 106, 619-651. [CrossRef]

6. Kolitsch, U.; Rieck, B.; Voudouris, P. Mineralogy and genesis of the Lavrion ore deposit: New insights from the study of ore and accessory minerals. Mitt. Österr. Mineral. Ges. 2015, 161, 66.

7. Skarpelis, N. The Lavrion deposit (SE Attika, Greece): Geology, mineralogy and minor elements chemistry. Neues Jahrb. Miner. Abh. J. Miner. Geochem. 2007, 183, 227-249.

8. Wendel, W.; Markl, G. Lavrion: Mineralogische Klassiker und Raritäten für Sammler. Lapis 1999, $24,34-52$. (In German)

9. Rieck, B.; Kolitsch, U.; Voudouris, P.; Giester, G.; Tzeferis, P. More new finds from Lavrion, Greece. Mineral.-Welt 2018, 29, 32-77. (In German)

10. Galanos, E.; Voudouris, P.; Rieck, B.; Kolitsch, U.; Mavrogonatos, C.; Melfos, V.; Zaimis, S.; Soukis, K. Oscillatory zoned gersdorffite and the $\mathrm{Ni}-\mathrm{Bi}$-Au association at Clemence Mine and $\mathrm{Km} 3$ locality, Lavrion District, Greece. In Proceedings of the 1st International Electronic Conference on Mineral Science; MDPI: Basel, Switzerland, 2018.

11. Garrels, R.M.; Christ, C.L. Solutions, Minerals and Equilibria; Harper and Row: New York, NY, USA, 1965; p. 450.

12. Henley, R.W.; Truesdell, A.H.; Barton, P.B.; Whitney, J.A. Fluid-mineral equilibria in hydrothermal systems. Rev. Econ. Geol. 1984, 1, 1-267.

13. Altherr, R.; Kreuzer, H.; Wendt, I.; Lenz, H.; Wagner, G.; Keller, J.; Harre, W.; Hohndorf, A. A late Oligocene/Early Miocene high temperature belt in the Attic-Cycladic crystalline complex (SE Pelagonian, Greece). Geol. Jahrb. 1982, 23, 97-164.

14. Jolivet, L.; Brun, J.P. Cenozoic geodynamic evolution of the Aegean region. Int. J. Earth Sci. 2010, 99, 109-138. [CrossRef]

15. Photiades, A.; Carras, N. Stratigraphy and geological structure of the Lavrion area (Attica, Greece). Bull. Geol. Soc. Greece 2001, 34, 103-109. [CrossRef]

16. Papanikolaou, D.J.; Syskakis, D. Geometry of acid intrusives in Plaka, Laurium and relation between magmatism and deformation. Bull. Geol. Soc. Greece 1991, 25, 355-368.

17. Baltatzis, E. Contact metamorphism of a calc-silicate hornfels from Plaka area, Laurium, Greece. Neues Jahrb. Miner. Monatsh. 1981, 11, 481-488.

18. Bassi, E.; Soukis, K.; Lekkas, S. The presence of Vari-Kirou Pira unit at Panion Hill (SE Attica, Greece). Bull. Geol. Soc. Greece 2004, 36, 1608-1617. [CrossRef]

19. Photiades, A.; Saccani, E. Geochemistry and tectono-magmatic significance of HP/LT metaophiolites of the Attic-Cycladic zone in the Lavrion area (Attica, Greece). Ofioliti 2006, 31, 89-102.

20. Berger, A.; Schneider, D.A.; Grasemann, B.; Stöckli, D. Footwall mineralization during Late Miocene extension along the West Cycladic Detachment System, Lavrion, Greece. Terra Nova 2013, 25, 181-191. [CrossRef]

21. Scheffer, C.; Vanderhaeghe, O.; Lanari, P.; Tarantola, A.; Ponthus, L.; Photiades, A.; France, L. Syn- to post-orogenic exhumation of metamorphic nappes: Structure and thermobarometry of the western Attic-Cycladic metamorphic complex (Lavrion, Greece). J. Geodyn. 2016, 96, 174-193. [CrossRef]

22. Scheffer, C.; Tarantola, A.; Vanderhaeghe, O.; Rigaudier, T.; Photiades, A. $\mathrm{CO}_{2}$ flow during orogenic gravitational collapse: Syntectonic decarbonation and fluid mixing at the ductile-brittle transition (Lavrion, Greece). Chem. Geol. 2017, 450, 248-263. [CrossRef]

23. Altherr, R.; Siebel, W. I-type plutonism in a continental back-arc setting: Miocene granitoids and monzonites from the central Aegean Sea, Greece. Contrib. Miner. Petrol. 2002, 143, 397-415. [CrossRef]

24. Skarpelis, N.; Tsikouras, B.; Pe-Piper, G. The Miocene igneous rocks in the Basal unit of Lavrion (SE Attica Greece): Petrology and geodynamic implications. Geol. Mag. 2008, 145, 1-15. [CrossRef]

25. Peccerillo, A.; Taylor, S.R. Geochemistry of Eocene calc-alkaline volcanic rocks from the Kastamonu area, northern Turkey. Contrib. Mineral. Petrol. 1976, 58, 63-81. [CrossRef]

26. Middlemost, E.A.K. Magmas and Magmatic Rocks: An Introduction to Igneous Petrology; U.S. Department of Energy Office of Scientific and Technical Information: New York, NY, USA, 1985.

27. Shand, S.J. The Eruptive Rocks, 2nd ed.; John Wiley: New York, NY, USA, 1943.

28. Maniar, P.D.; Piccoli, P.M. Tectonic discrimination of granitoids. Geol. Soc. Am. Bull. 1989, 101, 635-643. [CrossRef] 
29. Stouraiti, C.; Mitropoulos, P.; Tarney, J.; Barreiro, B.; McGrath, A.M.; Baltatzis, E. Geochemistry and petrogenesis of late Miocene granitoids, Cyclades, southern Aegean: Nature of source components. Lithos 2010, 114, 337-352. [CrossRef]

30. Kissin, S.A. Five-element (Ni-Co-As-Ag-Bi) veins. Geosci. Can. 1992, 19, 113-124.

31. Markl, G.; Burisch, M.; Neumann, U. Natural fracking and the genesis of five-element veins. Miner. Depos. 2016, 51, 703-712. [CrossRef]

32. Choi, S.G.; Youm, S.J. Compositional variation of arsenopyrite and fluid evolution at the Ulsan deposit, southeastern Korea: A low-sulfidation porphyry system. Can. Mineral. 2000, 38, 567-583. [CrossRef]

33. Henning, A.; Van der Westhuizen, W.A.; De Bruiyn, H.; Beukes, G.J. Hydrothermal Cu-Ni-Au-Ag mineralization in a granodiorite sill north of Cradock, Republic of South Africa. Miner. Depos. 1997, 32, 410-418. [CrossRef]

34. Seifert, T.; Sandmann, D. Metallogeny and economic potential of tungsten deposits in the Erzgebirge, Saxony/Bohemia. In Proceedings of the 33rd International Geological Congress-MRD04 Giant Ore Deposits, Oslo, Norway, 6-14 August 2008.

35. Staude, S.; Werner, W.; Mordhorst, T.; Wemmer, K.; Jacob, D.E.; Markl, G. Multi-stage Ag-Bi-Co-Ni-U and $\mathrm{Cu}$-Bi vein mineralization at Wittichen, Schwarzwald, SW Germany: Geological setting, ore mineralogy, and fluid evolution. Miner. Depos. 2012, 47, 251-276. [CrossRef]

36. Ahmed, A.H.; Arai, S.; Ikenne, M. Mineralogy and paragenesis of the Co-Ni arsenide ores of Bou Azzer, Anti-Atlas, Morocco. Econ. Geol. 2009, 104, 249-266. [CrossRef]

37. Marshall, D.D.; Diamond, L.W.; Skippen, G.B. Silver transport and deposition at Cobalt, Ontario, Canada: Fluid inclusion evidence. Econ. Geol. 1993, 88, 837-854. [CrossRef]

38. Essarraj, S.; Boiron, M.C.; Cathelineau, M.; Tarantola, A.; Mathieu Leisen, M.; Boulvais, P.; Maacha, L. Basinal brines at the Origin of the Imiter Ag-Hg Deposit (Anti-Atlas, Morocco): Evidence from LA-ICP-MS data on fluid inclusions, halogen signatures, and stable isotoped (H, C, O). Econ. Geol. 2016, 111, 1753-1781. [CrossRef]

39. Pažout, R.; Šrein, V.; Korbelová, Z. An unusual Ni-Sb-Ag-Au association of ullmannite, allargentum, $\mathrm{Au}$-rich silver and Au-bearing dyscrasite from Oselské pásmo "silver" Lode of Kutná Hora Pb-Zn-Ag ore district (Czech Republic). J. Geosci. 2017, 62, 247-252. [CrossRef]

40. Scheffer, C.; Tarantola, A.; Vanderhaeghe, O.; Voudouris, P.; Rigaudier, T.; Photiades, A.; Morin, D.; Alloucherie, A. The Lavrion Pb-Zn-Fe-Cu-Ag detachment-related district (Attica, Greece): Structural control on hydrothermal flow and element transfer-deposition. Tectonophysics 2017, 717, 607-627. [CrossRef]

41. Plotinskaya, O.Y.; Rusinov, V.L.; Seltmann, R. Oscillatory zoning fahlores from Au-Ag epithermal deposits. Goldschmidt Conf. Abstr. 2007, A796, 910-931.

42. Deditius, A.P.; Utsunomiya, S.; Renock, D.; Ewing, R.C.; Ramana, C.V.; Becker, U.; Kesler, S.E. A proposed new form of arsenian pyrite: Composition, nanostructure and geochemical significance. Geochim. Cosmochim. Acta 2008, 72, 2919-2933. [CrossRef]

43. Grabezhev, A.; Voudouris, P. Rhenium distribution in molybdenite from Vosnesensk porphyry $\mathrm{Cu} \pm(\mathrm{Mo}-\mathrm{Au})$ deposit (southern Urals, Russia). Can. Mineral. 2014, 52, 671-686. [CrossRef]

44. Fanlo, I.; Subías, I.; Gervilla, F.; Paniagua, A.; García, B. The composition of Co-Ni-Fe sulfarsenides, diarsenides and triarsenides from the San Juan de Plan deposit, central Pyrenees, Spain. Can. Mineral. 2004, 42, 1221-1240. [CrossRef]

45. Kiefer, S.; Majzlan, J.; Chovan, M.; Števko, M. Mineral compositions and phase relations of the complex sulfarsenides and arsenides from Dobšiná (Western Carpathians, Slovakia). Ore Geol. Rev. 2017, 89, 894-908. [CrossRef]

46. Radosavljević, S.A.; Stojanović, J.N.; Vuković, N.S.; Radosavljević-Mihajlović, A.S.; Kašić, V.D. Low-temperature Ni-As-Sb-S mineralization of the $\mathrm{Pb}(\mathrm{Ag})-\mathrm{Zn}$ deposits within the Rogozna ore field, Serbo-Macedonian Metallogenic Province: Ore mineralogy, crystal chemistry and paragenetic relationships. Ore Geol. Rev. 2015, 65, 213-227. [CrossRef]

47. Shore, M.; Fowler, A.D. Oscillatory zoning in minerals: A common phenomenon. Can. Mineral. 1996, 34, 1111-1126.

48. Kretschmar, U.; Scott, S.D. Phase relations involving arsenopyrite in the system Fe-As-S and their application. Can. Mineral. 1976, 14, 364-386. 
49. Sharp, Z.D.; Essene, E.J.; Kelly, W.C. A re-examination of the arsenopyrite geothermometer: Pressure considerations and applications to natural assemblages. Can. Mineral. 1985, 23, 517-534.

50. Scott, S.D.; Barnes, H.L. Sphalerite geothermometry and geobarometry. Econ. Geol. 1971, 66, 653-669. [CrossRef]

51. Barton, P.B.J.; Skinner, B.J. Sulfide mineral stabilities. In Geochemistry of Hydrothermal Ore Deposits; Barnes, H.L., Ed.; Wiley Interscience: New York, NY, USA, 1979; pp. 278-403.

52. Rieck, B. Seltene Arsenate aus der Kamariza und weitere Neufunde aus Lavrion. Lapis 1999, 24, 68-76.

(C) 2018 by the authors. Licensee MDPI, Basel, Switzerland. This article is an open access article distributed under the terms and conditions of the Creative Commons Attribution (CC BY) license (http://creativecommons.org/licenses/by/4.0/). 